\title{
STUDIES ON THE BLOOD SEDIMENTATION RATE IN LEPROSY PATIENTS
}

Part 1. The Types of Leprosy and B. S. R.

Part 2. The Correlation of B.S. R. and Tuberculin Test.

\section{TAKEYO TAKAHASHI}

\author{
Oshima Seisho-en National Leprosarium (Director T. Nojima)
}

The acceleration of blood sedimentation is generally recognized in serious leprosy patients, though the reason of it is not yet thoroughly clarified. This experiment has been carried out in order to investigate the correlation between leprosy types and $\mathrm{B}$. S. $\mathrm{R}$. and to reseach for the accelerating factors, frequent blood sedimentation tests with many patients over the long treatment period in the Oshima Seisho-en and by animal experiment with rabbits.

In this paper Part 1 the correlation of leprosy types and B.S.R. is referred.

The number of patients tests was 209 without any complication, and their types, lepromatous 133, neural 64, tuberculoid 12. The ages were ranging from 5 to 52 years, and the course from 1 to 33 years since the initiation of the disease. The measurement was carried out by Westergren's method three times at three months interval and the fourth measurement after five years. The experiment informed of the following facts.

1) B.S. R. of lepra patients is generally more accelerated than that of healthy people.

2) Tuberculoid, neural and lepromatous types take turns in the acceleration. In the lepromatous it is most remarkable, especially due to the aggravation of the disease.

3) The ratio of acceleration keeps a direct proportion with seriousness of disease.

The paper Part 2 mentioned the correlation of B.S. R. to tuberculin test. The examination was made with 209 patients ( $\mathrm{L} \mathrm{133,N} 64$ and T 12), from whom tuberculous diseases could be stricktly excluded. The results are presented beneath.

1) The negativity and positivity show no significant difference in any type of leprosy.

2) Comparing of tuberculin positivity (presented in $++H+$ ) or negativity with B.S. $\mathrm{R}$., the latter is not in accordance with tuberculin-positivity.

\section{癩患者の赤血球沈降反応に関する研究（1-2)}

\author{
国立療養所大島青松園（園長 野島泰治博士） \\ 厚生技官高橋竹代 \\ (昭和 29 年 2 月 24 日受稿)
}

\section{第 I 篇 癩病型と赤血球沈降速度}

\footnotetext{
第 1 章 緒 言

1918年 Fahraeus によつて妊娠反心として見出された 赤血球沈降反応（以下赤沈と略称す）は，其の後，諸家 の研究によつて一般疾患に於ても促進するととが明かと なり，今日では疾病の診断と治療指針，预後判定の補助 として広くこれを用いられるよらになつた。赤沈の本態 については各方面から研究が進められ，先ず促進的因子
}

として血漿フイブリノーゲン，並にグロブリンの增加， 血漿中残余䇺素の増加，血漿粘稠度上昇，赤血球数の诚 少，血色素指数の増加が挙げられ，抑制的因子としては 血漿アルブミンの増加, 赤血球の増加, 胆汁酸並に岸酸 瓦斯量の増加，血色素指数の減少が数えられている。し かし個々の疾患に於ける赤沈促進因子については，い末 だ充分解明されていないものが多いようである。 
さて櫴の赤沈については Frazier and W $\mathbf{u}^{1)}$ を始め我

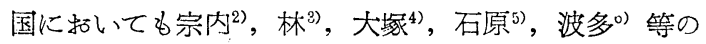
報告がもつていずれる重症顆では赤沈の著しい促進を認 めている。そしてこれが促進团子については大冢はフィ ブッノーグン及び血糖との 関係を論じ，石原は $\gamma$ グロ ブリンの関係を, 又波多はヒスタミンとの関連を述べて いるが之等はいずれる患者のみを対象とした稍々断片的 な観祭の感がないでもない。そてで私は本園に於ける多 数の瀨患者を刘象として長期の治療期間中数回に亘つて 赤沈值の㭘查を行い，こ犰が病状との関連性並化促進因 子学追筞する傍ら一方では家雨を使用して実験的研究を 進め相俟つて瀨の赤沈促進因子炕ついて若下の考祭を試 みたので以下篇を雷和てその成績を述べたいと思ら。本 䇾では先ず赤㳔と病刑，病状の関係について还べたい。

\section{第 2 章 実験方法}

測定法：Westergren氏法に依り，測定価は中等価をと つた。

瀨患者：合併症を認めない209名（結節嶰 133 名, 神

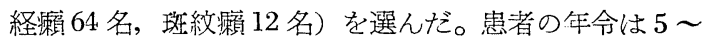
52 才，発病後 1 〜3年を経過したもので岁る。测定は同 一患者について 3 力月每比 3 回行い, 第 4 回目は 5 年後 に行つたものでせる。

\section{第 3 章 実験成績}

第 1 節 各病型别赤沈比較（第 1 表及第 1 汹参照）

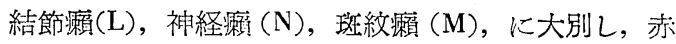
沈值を $0 \sim 19 ， 20 \sim 29 ， 30 \sim 49 ， 50 \sim 99 ， 100$ 以上の 5 群に分けて表示したものについて見ると，4回とる略々 同様の战績を示している。

即ち結節顆では每回検査数の約 $50 \%$ は 30 以上の赤沈傾 を示し, 神経頖では30以上を示するのは僅か約15\%, 班紋顆では一層䟞く 4 回の検査に㧊いて1例を認めたに 過ぎない。更に各病型について其の病症の程度 $\mathrm{L}_{3} \sim \mathrm{L}_{1}$, $\mathrm{N}_{3} \sim \mathrm{N}_{1}, \mathrm{M}_{2} \sim \mathrm{M}_{1}$ との関係を仔細に観祭するにとの場合 も重症のもの程赤沈が促進されているととが梅めて明か である。そして之等の平均曲線は例外なく見謽な下降曲 線を画いている。

但し個々の症例中には重症にして赤沈值の低いもの，

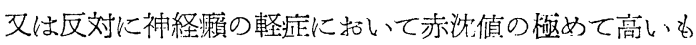
のが少数に見られた。

\section{第 2 節 㿎病型及病状の推移と赤沈の関係(第2戍参照)}

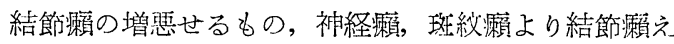
移行せるものについてその前後の赤沈值を比較したに，

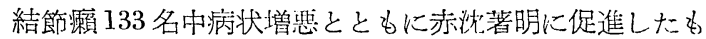
の 40 名 $(30 \%)$, 変化なきもの 4 名, $(3 \%)$, 病状は著

第 1 表 病型別赤沈比較

\begin{tabular}{|c|c|c|c|c|c|c|c|c|c|c|c|c|c|c|c|c|c|c|c|c|}
\hline 赤泌靣数 & E & & 1 & & 回 & 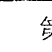 & & 2 & & 回 & & 兒 & 3 & & 回 & & 第 & 4 & & 回 \\
\hline 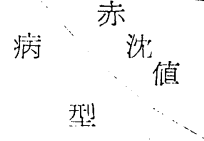 & \begin{tabular}{l|} 
湌 \\
查 \\
数
\end{tabular} & 19 & 29 & $\int_{49}^{30}$ & $\left.\right|_{99} ^{50}$ & $\begin{array}{l}\text { 検 } \\
\text { 查 } \\
\text { 数 }\end{array}$ & & $\int_{29}^{20}$ & 49 & $\left.\right|_{99} ^{50} 100$ & $\begin{array}{l}\text { 検 } \\
\text { 査 } \\
\text { 数 }\end{array}$ & 19 & 29 & $\int_{49}^{30}$ & $\left.\right|_{9} ^{50}$ & $\begin{array}{l}\text { 榆 } \\
\text { 査 } \\
\text { 数 }\end{array}$ & $\prod_{19}^{0}$ & $\left.\right|_{29} ^{20}$ & & $\begin{array}{l:l}50 & 10 \\
1 & \\
99 & \end{array}$ \\
\hline 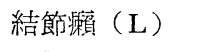 & 3 & 50 & 12 & 26 & \begin{tabular}{l|l}
45 & 0
\end{tabular} & 125 & 37 & 20 & 28 & \begin{tabular}{l|l|}
38 & 2
\end{tabular} & 128 & 33 & 26 & 21 & 45 & 99 & 15 & 7 & 16 & \begin{tabular}{l|l}
4.3 & 1
\end{tabular} \\
\hline $\mathrm{L}$ & & 3 & 1 & $|11|$ & $24: 0$ & 37 & 5 & 2 & & \begin{tabular}{l|l}
22 & 2
\end{tabular} & 3 & & 2 & & $23 \mid 2$ & 58 & 3 & 1 & & 31 \\
\hline $\mathrm{L}$ & 43 & 17 & 4 & 9 & 130 & 42 & 10 & 10 & 11 & 110 & 43 & 9 & 11 & 7 & $\begin{array}{ll}15 & 1\end{array}$ & 21 & 5 & 3 & 4 & 6 \\
\hline $\mathrm{L}$ & 51 & 30 & 7 & 6 & 8 & 46 & 22 & 8 & 11 & \begin{tabular}{l|l}
5 & 0
\end{tabular} & & 22 & 13 & 8 & $\begin{array}{ll}7 & 0\end{array}$ & 20 & 7 & 3 & 4 & 6 \\
\hline 神経癩 (N) & 64 & $47^{\prime}$ & 7 & 6 & 4 & 58 & 41 & 9 & 7 & \begin{tabular}{l|l}
1 & 0
\end{tabular} & 61 & 41 & 11 & 4. & \begin{tabular}{|l|l|}
5 & 0 \\
\end{tabular} & 29 & 18 & 7 & 4 & 0 \\
\hline $\mathrm{N}_{3}$ & 9 & 5 & 2 & 0 & \begin{tabular}{l|l}
2 & 0
\end{tabular} & & 7 & 0 & 0 & 1 & 9 & 5 & 2 & 0 & 2 & 7 & 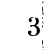 & 2 & 2 & 0 \\
\hline $\mathrm{N}$ & & 12 & 2 & 1 & 1 & 15 & 12 & 2 & 1 & $\begin{array}{ll}0 & 0\end{array}$ & 13 & 8 & 4 & 0 & 1 & 9 & 6 & 1 & 2 & 0 \\
\hline $\mathrm{N}_{1}$ & 1 & 30 & 3 & 5 & 1 & 35 & 22 & 7 & 6 & $0: 0$ & 39 & 28 & 5 & 4 & $\begin{array}{ll}2 & 0\end{array}$ & 13 & 9) & 4 & 0 & 0 \\
\hline 斑紋瀨（M) & 12 & 10 & 1 & 0 & 1 & 11 & 11 & 0 & 0 & $\begin{array}{ll}0 & 0\end{array}$ & 11 & 9 & 2 & 0 & $\begin{array}{lll}0 & 0 \\
\end{array}$ & ] & 1 & 0 & $0^{\prime}$ & 0 \\
\hline $\mathrm{M}_{2}$ & 5 & 3 & 1 & 0 & 1 & 3 & 3 & 0 & 0 & 0 & 3 & 1 & 2 & 0 & $\mid \begin{array}{lll}0 & 0\end{array}$ & 0 & $0_{i}$ & 0 & 0 & 0 \\
\hline $\mathbf{M}_{1}$ & 7 & 7 & 0 & 0 & 0 & 8 & 8 & 0 & 0 & 0 & 8 & 8 & 0 & 0 & $0_{0}$ & 1 & 1 & 0 & 0 & 0 \\
\hline
\end{tabular}



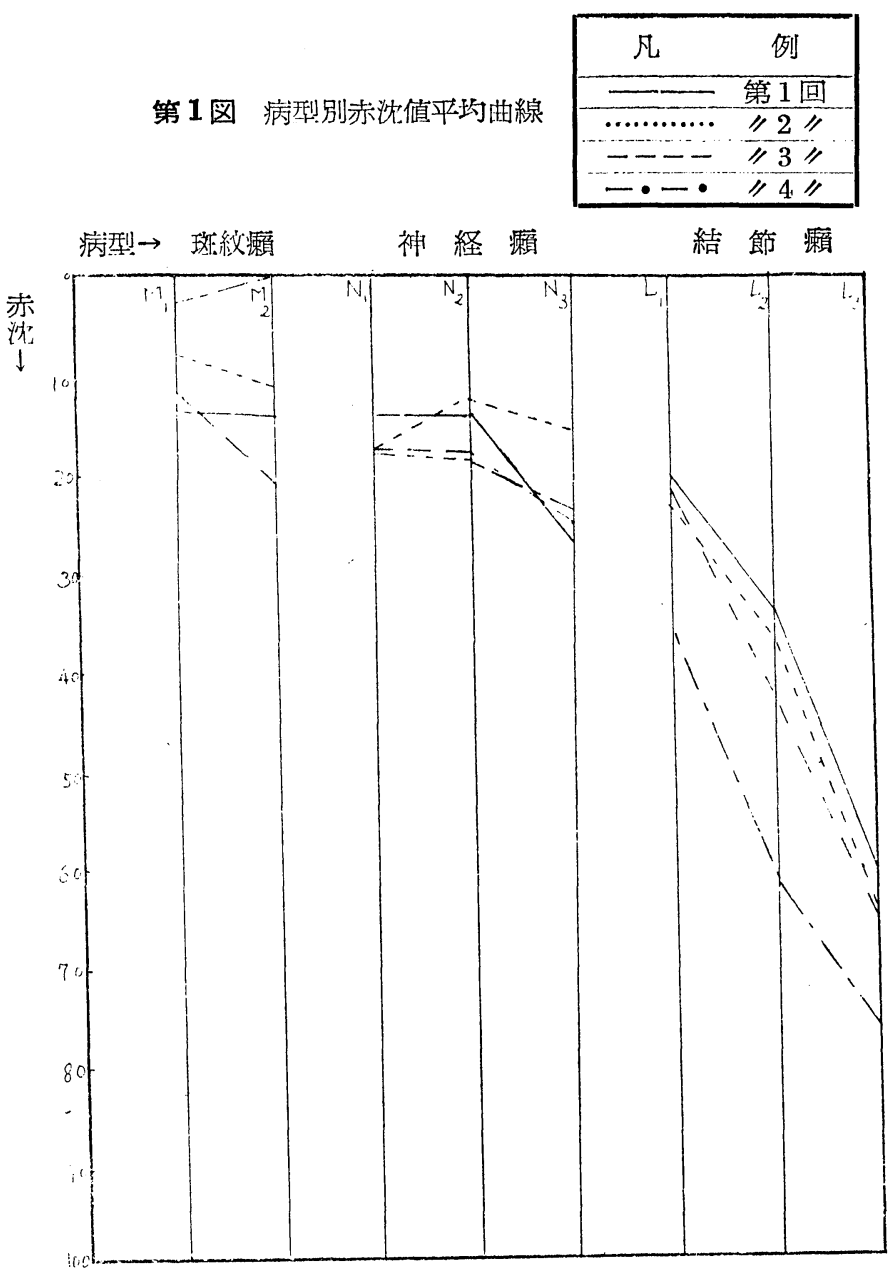

しく増悪しないが赤沈が促進したもの 25 名, (19\%，との 中の大部分は $\mathrm{L}_{3}$ でもる), 又, 神経瀨, 斑紋瀨76名中, 結節䫀え移行したもの21名, 中, 赤沈促進したもの18名 で他の 3 名は変化がなかつた。結節癩 $\mathrm{L}_{2}$ より $\mathrm{L}_{1}$ に軽快 した 3 例では 1 例は変化なく， 2 例が遅死した。

\section{第 4 章 総 括}

以上の成績から次のような叓実を知るととが出来た。 1）一般に癩患者の赤沈は健㢃者赤沈に比して速かて る。
2）三病型中斑紋癩は殆ど変化なきか或は侣かに促進 されるが, 神経瀨では促進されたもの多く, 結節瀨に打 いては最も著明でもり且病状重篤な例性ど赤沈速度が速 かでめる。

3）但し重症例と雖も中には赤沈值の低いものがあ り, 又神経型の轻掂例中にも赤沈の極めて速いものがも つた。

4）同一患者に括いても病状の增悪した場合は促進さ れ, 軽快の際は遲延する。 即ち癩では重庭な例性ど赤沈值が多いととを知つた。 
凡 例

第 2 図 病型，病状の推移と赤沈の変化

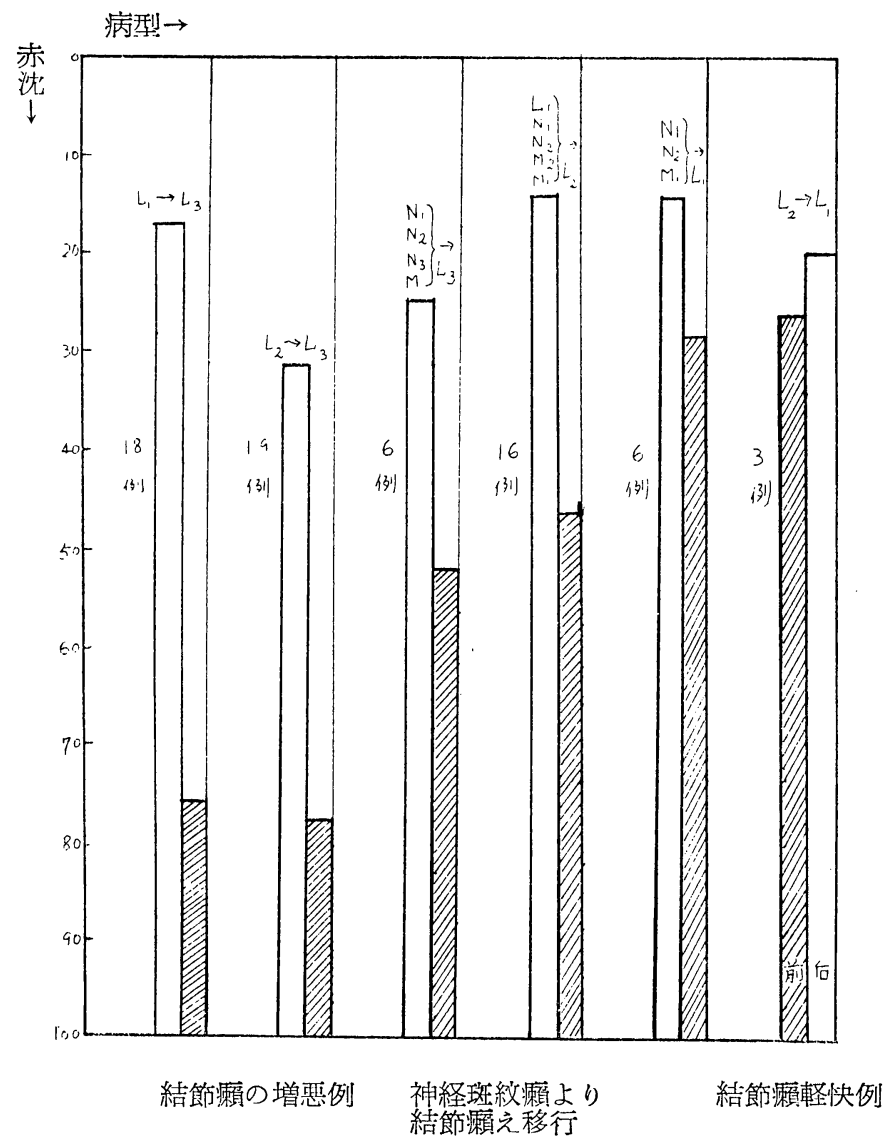

\section{第 II 篇 癩に於ける赤沈と「ツ」反応との関係}

\section{第 1 章 小 引}

瀬の「ッベルクリン」反応関しては五十峝7), 田尻8), 郮方9)，等の研究があつて，いずれも病型とは関連のな いととを唱えている。著者は第 1 篇記述の如く結核其の 他の合併症を厳に除外した癩患者についてその病型別に 赤沈速度を調べると同時に「ッ」反応との関連について 調查を試みた。以下その成績を述べたいと思ら。

\section{第 2 章 実験方法}

実験に採用した患者は第 1 篇記载のもの 209 名（結節 灀133名, 神経賴64名, 斑紋櫴12名)で赤沈の測定と同時 に次の方法で 4 回に亘つて「ッ」反㐫を試みた。即ち型
の如く旧ッベルクリン2.000倍液 $0,1 \mathrm{cc}$ 視患者前膊内側 の皮内に注射し 48 時間後に其の発赤, 腫脤, 水泡形成な ぞを検し次の方式に従い判定した。発赤 $4 \mathrm{~m} . \mathrm{m}$. 以下を陰 性 $(-)$, 発赤 5 10m.m.を疑陽性 (土), 発赤 $10 \mathrm{~m} . \mathrm{m}$. 以上 を弱陽性 $(+)$, 発赤 $10 \mathrm{~m} . \mathrm{m}$. 以上で硬結を伴らものを中 等度陽性 $(H)$, 発赤 $10 \mathrm{~m} . \mathrm{m}$. 以上で硬結二重発赤比水泡 或は Necrose を伴らものを強陽性(HH)とした。以下「ッ」 反応程度を $(-),( \pm),(+),(H),(H+)$, の附号を以 つて表す。沿赤沈值は中等価をとつた。

\section{第 3 章 実験成績}

第 1 節 病型, 病狀别による「ツ」反応成績（第 2 表 参照) 
第 2 表瀨 病型と「ッ」反心

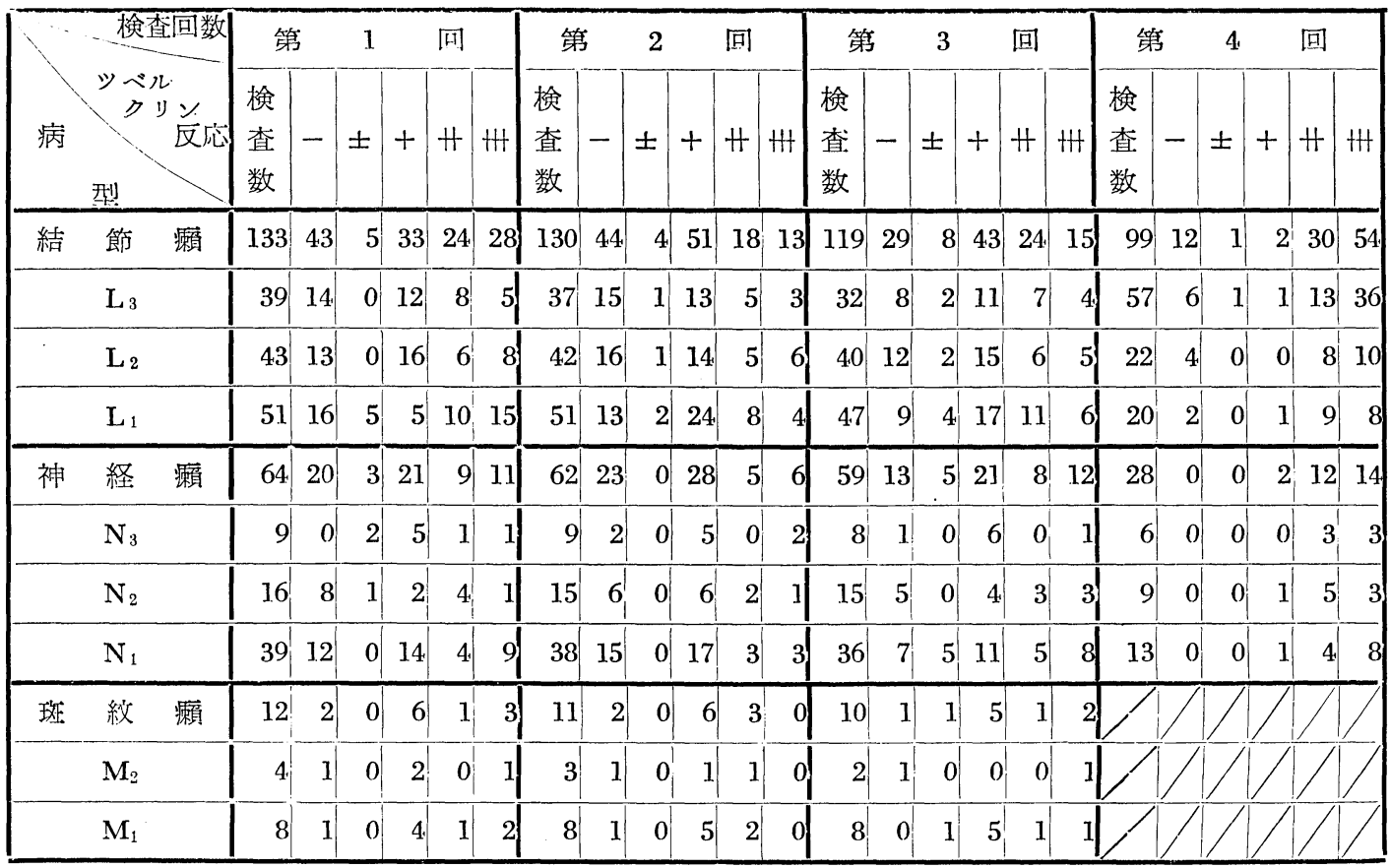

此の表によると，第 1 回では結節癩 133 例中「ッ」反 忍は43例即ち約 $1 / 3$ が㓌性で, 残り ${ }^{2} / 3$ は(士)〜(H)までの

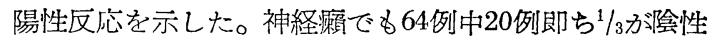
で，他の $2 / 3$ は (土)〜 (Ht) 索での陽性反応を現わしてい る。文斑紋癩では12例の小数で耊るが 2 例 $1 / 6$ が陰性で他 は陽性である。

又同一病型に扔いても病状の程度 $\mathrm{L}_{1} \sim \mathrm{L}_{3}$ 及び $\mathrm{N}_{1} \sim \mathrm{N}_{3}$ によつて反応の現われ方に殆ど相違を認めない。このよ 万な成績は第 2 〜第 4 回の検査に颃いても見られるとと ろで心るから，私はてれによつて先人と同様に㿎病型及 び病状が「ッ」反応と全く関係を持たないととを確認し た。

\section{第 2 節「ツ」反応と赤沈値の関係（第 3 表参照）}

先ず第 1 回「ッ」反応 $($ 一)の65例について赤沈值平均 を見るに結節瀨43例の平均 38 ，神経，斑紋櫴 22 例の平圴 15を示し，「ッ」反応 (fHt) の42例では結節瀬28例の平约 42, 神経濑, 斑紋瀬14例の平圴 14 , である。このように 結節癩赤沈值平圴と神経, 斑紋瀨のそれの間には両者と も可成りの相違が認められるが,「ッ」反応との関係では 殆ど偏差がない。其の間, .(十), (H)程度の例を採り上 げても略々同様に「ッ」反応の陰性, 陽性, 又は陽性の 程度によつて，赤沈值が影響を受けているとは考えられ ない。そしてとの成績は第 2 第 4 回の成績を通じ䀩々 同様の傾向を示している。

な打同一病型に扔いても症状の増覀した場合, 又は N. M 型より L 型え移行した場合は赤沈の促進を認女た が「ッ」区忍には殆んど影響を見なかつた。

即ち以上の成績によつて赤沈值は「ッ」反応と関連を 持たないるので耊るととが明かになつた。
第3表 $ッ$ 区応之赤沈值

\begin{tabular}{|c|c|c|c|c|c|c|c|c|c|}
\hline \multirow{2}{*}{$\begin{array}{l}\text { 产 } \\
\text { 応 } \\
\text { 応 }\end{array}$} & \multirow{2}{*}{$\begin{array}{l}\text { 病 } \\
\text { 型 }\end{array}$} & \multicolumn{2}{|c|}{ 第 1 回 } & \multicolumn{2}{|c|}{ 第 2 回 } & \multicolumn{2}{|c|}{ 第 3 回 } & \multicolumn{2}{|c|}{ 第 4 回 } \\
\hline & & $\begin{array}{l}\text { 検査 } \\
\text { | 数 }\end{array}$ & 赤沈 & $\begin{array}{l}\text { 検査 } \\
\text { 数 }\end{array}$ & 赤沈 & 検查 & 赤沈 & $\begin{array}{l}\text { 検査 } \\
\text { 数 }\end{array}$ & \\
\hline \multirow{2}{*}{$(-)$} & $\mathrm{L}$ & 43 & 38 & 4.4 & 45 & 29 & 46 & 12 & 60 \\
\hline & N.M. & 22 & 15 & 25 & 13 & 14 & 16 & & \\
\hline \multirow{2}{*}{$( \pm)$} & L & 5 & 17 & 4 & 26 & 8 & 25 & 1 & 110 \\
\hline & N.M. & 3 & 6 & & & 6 & 11 & & \\
\hline \multirow{2}{*}{$(+)$} & L & 33 & 36 & 51 & 35 & 43 & 37 & 2 & 16 \\
\hline & N.M. & 27 & 18 & 34 & 15 & 26 & 22 & 2 & 6 \\
\hline \multirow{2}{*}{$(H)$} & L & 24 & 40 & 18 & 46 & 24 & 44 & 30 & 56 \\
\hline & N.M. & 10 & 11 & 8 & 16 & 9 & 11 & 12 & 19 \\
\hline \multirow{2}{*}{$(t+t)$} & $\mathrm{L}$ & 28 & 42 & 13 & 45 & 15 & 49 & 54 & 64 \\
\hline & N.M. & 14 & 14 & 6 & 15 & 14 & 14 & 14 & 18 \\
\hline
\end{tabular}

\section{第 4 翰 総 括}

以上の成績を総括すると

1）癩に括いてはどの病型でも「ッ」区忍の陰性率, 及び陽性率に大差がない。

「ッ」反応陰性及び陽性度 (十, H, H H ) と赤沈值と を比較するに赤沈值は「ッ」反忍と一致しない。

即ちとれによつて「ッ」反忍と赤沈值との間には何等 の関連性を見出すととが出来なかつた。 